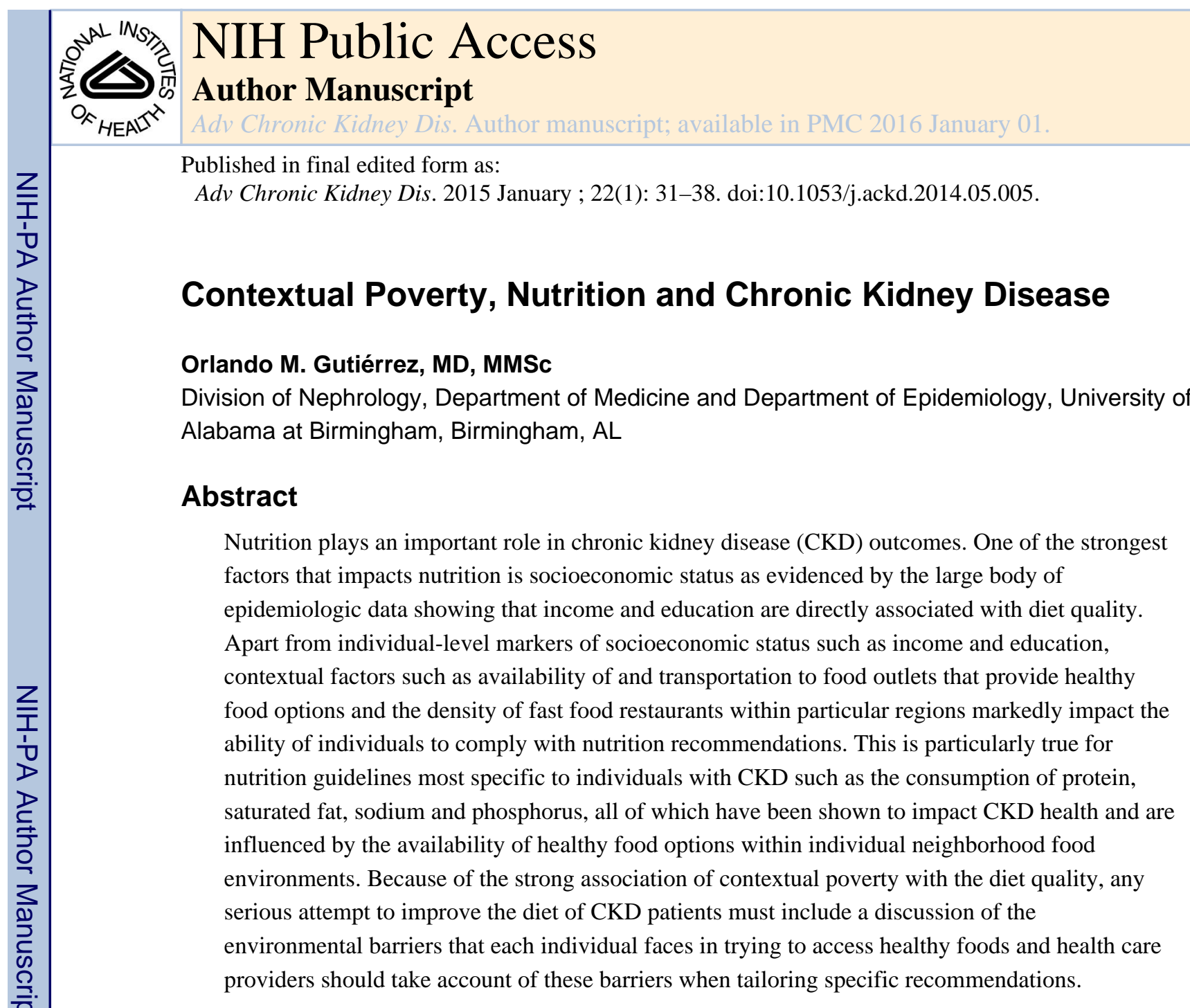

Keywords

nutrition; diet; poverty; sodium; fat

\title{
INTRODUCTION
}

Nutrition plays a vital role in chronic kidney disease (CKD) outcomes. Protein-energy wasting, sarcopenia and inflammation are among the strongest risk factors for death in individuals with end-stage renal disease (ESRD). ${ }^{1,2}$ Even among those with mild to moderate degrees of kidney dysfunction, nutrition can be mechanistically linked either directly or indirectly with key components of CKD care including blood pressure control and the management of dyslipidemia, diabetes, anemia, metabolic acidosis and disorders of

(C) 2014 The National Kidney Foundation, Inc. Published by Elsevier Inc. All rights reserved.

Corresponding author: Orlando M. Gutiérrez, MD, MMSc, University of Alabama at Birmingham, ZRB 614, $17202^{\text {nd }}$ AVE S., Birmingham, AL, 35294-0006, phone: 205-996-2736 fax: 205-996-6465 ogutierr@uab.edu.

Financial disclosures: None

Publisher's Disclaimer: This is a PDF file of an unedited manuscript that has been accepted for publication. As a service to our customers we are providing this early version of the manuscript. The manuscript will undergo copyediting, typesetting, and review of the resulting proof before it is published in its final citable form. Please note that during the production process errors may be discovered which could affect the content, and all legal disclaimers that apply to the journal pertain. 
bone and mineral metabolism. Given that nutrition impacts such a wide spectrum of factors related to CKD care, understanding the type and quantity of foods that an individual eats is essential for the management of patients with CKD.

Few factors influence the quality of foods that an individual consumes as much as socioeconomic status. Numerous studies have shown that lower indices of socioeconomic status are associated with higher consumption of foods linked with adverse metabolic and cardiovascular outcomes such as added fats, sugars, salt and refined grains, whereas higher socioeconomic status is associated with higher consumption of healthier food groups such as whole grains, fruits, vegetable and fish. ${ }^{3,4}$ While individual purchasing power plays an important role in the types of food that persons with CKD can buy and consume, it does not explain the entire picture, as factors such as the neighborhood one lives in, the supermarkets available in that neighborhood and surrounding areas, the availability of transportation to and from food outlets, and the density of fast food restaurants in a given area can influence the ability to find and purchase healthy foods (Figure). ${ }^{5,6}$ For individuals with CKD, these contextual factors may play an important and under-appreciated role in the management of diet in kidney disease. ${ }^{7}$

\section{Nutrition and Chronic Kidney Disease Outcomes}

The impact of nutrition on CKD outcomes has been the focus of several recent issues of Advances in Chronic Kidney Disease, and the reader is referred to two excellent contributions from these prior issues for a comprehensive review of nutritional factors that influence CKD health. ${ }^{8}{ }^{9}$ While a similar overview is beyond the scope of the current review, it is important to note that socioeconomic status and contextual poverty strongly influence consumption of many factors linked to CKD outcomes. Of particular interest are total energy intake and the consumption of key macronutrients (protein and fat) and micronutrients (sodium and phosphorus), the importance of which for kidney health are briefly reviewed below.

Excess caloric intake is a key factor underlying the development of obesity with important consequences for long-term kidney health. Higher body mass index and/or waist circumference have been linked to higher prevalence of kidney injury and excess risk of incident CKD and ESRD. ${ }^{10-17}$ Experimental data lend biological plausibility to these findings by showing that greater weight can contribute to glomerular hyperfiltration, fibrosis and ultimately, glomerulosclerosis. ${ }^{18-22}$ It is important to note, however, that the relationship of obesity with adverse outcomes in CKD is complicated by the finding that higher BMI, even when in the morbid range, has been associated with a survival benefit in some studies, ${ }^{23,24}$ perhaps owing to the impact of malnutrition-inflammation complex in individuals with severe kidney disease. ${ }^{25,} 26$ In addition, differences in body fat distribution and muscle mass may partly explain the obesity paradox as high waist circumference has been associated with increased risk of death in individuals with CKD even after adjustment for BMI. ${ }^{27,} 28$ Despite this, maintaining a healthy weight—in part via reduced caloric intake -remains part of current nutrition guidelines for optimizing CKD outcomes. ${ }^{29}$

Restriction of animal protein intake is also recommended for individuals with moderate to severe kidney disease who are not on dialysis to slow progression of CKD. ${ }^{29}$ Similarly, 
reduction in the intake of saturated fat - which often accompanies high animal protein intake -may preserve kidney function as evidenced by studies showing that excess saturated fat intake is associated with excess urinary albumin excretion, a strong risk factor for progression of CKD. ${ }^{30}$ The reasons for the apparent protective effects of reducing protein and/or saturated fat intake are unclear, but may be related to reduced synthesis of uremic toxins such as $p$-cresyl sulfate and indoxyl sulfate, lower endogenous acid production, improved endothelial function, or inhibition of inflammation. ${ }^{31-33}$

The consumption of micronutrients such as sodium and phosphorus have also been identified as important contributors to CKD outcomes. Large observational studies have shown that excess salt intake is associated with adverse health outcomes such as hypertension, volume overload and cardiovascular disease events. ${ }^{34,35}$ The clinical importance of these associations has been supported by randomized trials, ${ }^{36-39}$ including a recent study showing that lowering sodium intake resulted in clinically meaningful reductions in blood pressure, extracellular fluid volume, and albuminuria in individuals with moderate to severe CKD. ${ }^{40}$ Further, animal studies showed that excess dietary sodium intake induces left ventricular hypertrophy and promotes vascular damage. ${ }^{35,41}$ These effects may be magnified in individuals with $\mathrm{CKD}^{42}$ given their impaired neurohormonal mechanisms for enhancing excess sodium excretion in the urine, resulting in maladaptive increases in systemic blood pressure, renal plasma flow, and ultimately glomerular filtration pressure. ${ }^{43,44}$ All of these factors, in turn, can contribute to proteinuria and progression of renal failure in CKD patients. ${ }^{45,46}$

Excess phosphorus intake has long been implicated in the pathogenesis of kidney disease. Lower phosphorus intake reduced progression of kidney disease and improved survival in animals with experimentally-induced kidney disease. ${ }^{47-55}$ Although the effect of phosphorus restriction on CKD progression in humans has been examined in less detail, several small studies have shown a salutary effect of dietary phosphorus restriction on slowing progression of CKD. ${ }^{56-59}$ This has supported current recommendations to limit phosphorus intake in individuals with $\mathrm{CKD},{ }^{29}$ though the target level and best method to achieve this level remain unclear.

\section{Socioeconomic status and Nutrition in Chronic Kidney Disease}

Socioeconomic status impacts every aspect of diet quality and thus, strongly influences the ability of patients to comply with virtually all of the nutrition guidelines reviewed above. A substantial body of research has established that, as compared to individuals with greater socioeconomic status, individuals with lower socioeconomic status consume greater amounts of foods that can be directly linked with adverse metabolic, cardiovascular and kidney consequences. ${ }^{3}$ These socioeconomic gradients in diet quality immensely complicate the management of chronic disease conditions as evidenced by a multitude of studies showing that poverty is strongly associated with excess risk of diabetes, obesity, coronary artery disease and CKD. 7,60

Both individual-level and contextual socioeconomic status contribute to disparities in diet quality. Individual purchasing power relates to a person's ability to afford healthier foods like fresh fruits and vegetables which tend to be more expensive than highly processed and 
fast foods. Perhaps less well-recognized but equally as important are the contextual factors related to the neighborhood and surrounding communities within which an individual lives and that strongly impact decisions related to food purchase. ${ }^{5,61-67}$ For example, the concentration and availability of food outlets such as grocery stores and fast-food restaurants influence the ability of individuals to comply with specific dietary recommendations to help slow progression of CKD, and contribute to the development of food insecurity, defined as limited or uncertain ability to acquire nutritionally adequate and safe foods in socially acceptable ways. ${ }^{68}$ The influence of contextual socioeconomic factors on specific dietary recommendations in CKD patients are reviewed below.

Energy intake-Among the best documented associations of socioeconomic status with diet quality is the association of neighborhood/community characteristics with excess caloric intake and obesity. Individuals with fewer economic resources are more apt to purchase and consume energy-dense items that are nutrient poor and contribute to the development of disturbances in metabolic health such as central obesity, dyslipidemia, and insulin resistance. ${ }^{69}$ As a result, it is no surprise that rates of obesity are much higher in individuals with low income and educational achievement. These factors are compounded by inequitable access to healthy foods within low income communities. ${ }^{70}$ Studies have shown that individuals living in lower income neighborhoods with limited access to retail stores or food outlets that provide healthier food options consume higher amounts of energy-dense items than individuals living in higher income areas. ${ }^{71-75}$ Even among individuals with low income, greater access to stores that provide healthier food options has been associated with lower consumption of energy-dense items and higher consumption of fruits and vegetables suggesting that greater access to healthy food options can positively impact energy intake even among those with relatively limited purchasing power. ${ }^{76,77}$ This has also been shown to be the case for individuals participating in supplemental nutritional assistance programs, ${ }^{76}$ suggesting that public health strategies to improve nutrition should not focus solely on individual purchasing power but also the availability of grocery stores that sell healthy foods in impoverished areas. These findings have led to the definition of "food deserts," or areas in which access to stores is particularly limited, ${ }^{78}$ forcing individuals to purchase energy-dense food items which tend to be cheap and can last for extended periods of time on store shelves. When these factors are added to the general lack of resources for engaging in physical activity in low-income or rural areas, ${ }^{79-82}$ these critical aspects of the neighborhood food environment play an important role in contributing to a positive energy balance and the development of obesity. This likely also contributes to the relatively common co-occurrence of obesity and CKD in individuals living in low-income areas.

Protein and Saturated Fat Intake-Epidemiologic data on how socioeconomic status impacts protein intake have been mixed, with some studies showing that lower socioeconomic status is associated with higher protein intake and others showing the opposite. ${ }^{3}$ Evidence concerning the existence of socioeconomic gradients in the types of proteins being consumed are more consistent. In general, as compared to individuals with higher socioeconomic status, individuals with lower socioeconomic status consume fewer vegetable sources of protein, which are strongly linked with better health outcomes. ${ }^{3}$ This has important implications for individuals with CKD given that animal proteins contain high 
amounts of non-volatile acid which has been shown to promote glomerulosclerosis and fibrosis in animal models of kidney disease. ${ }^{33}$ Further, the types of animal meat products that those with lower income preferentially consume tend to include added fats, particularly saturated fat which is associated with excess cardiovascular and kidney disease.

There are relatively few data on the role of local food environments in the consumption of animal protein. However, the relationship between access to food stores and consumption of fruits and vegetables provide important clues. A large number of population-based studies have shown that lower access to supermarkets and grocery stores was associated with lower intake of fruits and vegetables. ${ }^{3}$ The importance of these findings for CKD patients was underscored by studies showing that consumption of a higher percentage of protein from plant sources was associated with higher bicarbonate levels in CKD patients, ${ }^{83,} 84$ and may help slow progression of CKD. ${ }^{85}$ Given that higher animal protein intake is commonly associated with lower fruit and vegetable intake, it is likely that the local food environment plays and important role in contributing to excess animal protein and saturated fat intake and their downstream consequence such as acid-loading, inflammation and endothelial dysfunction.

Sodium Intake-Socioeconomic status strongly impacts the consumption of sodium in the diet, largely by influencing the intake of foods that are rich in added salt or sodium-based food additives. It is estimated that $75 \%$ of salt intake comes from salt added to processed foods by manufacturers, and approximately $15 \%$ from salt added during cooking or other discretionary uses. ${ }^{86}$ In a large international study that estimated the quantity and sources of sodium intake in 4,680 individuals 40 to 59 years of age from Japan, the People's Republic of China, the United Kingdom and the United States, ${ }^{87}$ the majority of sodium intake in the United Kingdom and the United States was found to come from processed breads, cereals, grains, meats, sauces and canned items with only a very small fraction (5-10\%) coming from salt added in home cooking or at the table. ${ }^{88}$ These results indicate that added salt and sodium additives in processed foods represent the single greatest source of sodium intake in CKD patients living in Western countries.

The barrier that added salt or sodium-based food additives pose in reducing sodium intake in CKD patients is accentuated among those who do not have the financial means to purchase fresh foods or who do not have access to food sources that provide less processed foods. In a study of 2,384 participants of the Multi-Ethnic Study of Atherosclerosis (MESA), individuals with lower supermarket density within their region of residence or who reported lower perceived access to healthy foods were much more likely to report consuming fast and processed meats foods than individuals who lived in areas with higher supermarket density or had higher perceived access to healthy foods. ${ }^{63}$ Similar associations have been reported in other cohorts. ${ }^{89}$ Just as lack of access to healthy food options plays a major role in promoting consumption of unhealthy food options, excess access to fast food restaurants is associated with poor diet quality. Moore and colleagues examined participants of MESA who reported frequency of fast food consumption and found that for every standard deviation increase in the density of fast food exposure, the odds of consuming a diet pattern characterized by high intake of fast foods and processed meats diet increased by 12 to $17 \%$, in line with what has been reported in other studies. ${ }^{64}$ Importantly, areas with lower access 
to supermarkets or that have high proximity to fast-food restaurants have disproportionately high prevalence rates of individuals with low annual family income, ${ }^{90}$ underscoring how contextual poverty accentuates the difficulties of finding and purchasing non-processed food items for individuals with already limited financial means.

While neighborhood characteristics clearly influence consumption of processed and fast foods, less is known about their specific impact on sodium consumption. A study of 2,266 individuals participating in a Japanese occupational cohort showed that lower education and household income levels were associated with higher intake of sodium intake as ascertained from a self-administered diet history questionnaire. ${ }^{91}$ Unfortunately, no data were reported with respect to the association of neighborhood characteristics with salt intake in this study. In a study of 182 children living in the Birmingham, AL metropolitan area, residence in disadvantaged neighborhoods (as determined by census tract-related measures of unemployment and poverty) was associated with higher salt intake as determined by two 24hour diet recalls. ${ }^{92}$ In one of the few studies investigating the association of neighborhood characteristics with urinary sodium excretion as an alternate index of dietary sodium consumption, Murakami et al. examined the relationship between municipal-level indices of neighborhood socioeconomic status (e.g., unemployment, home ownership, overcrowding, etc.) and 24-hour urinary sodium excretion in 1,032 female Japanese dietetic students 18 to 22 years of age. ${ }^{93}$ These investigators found no statistically significant association of neighborhood characteristics with 24-hour urinary sodium or potassium excretion when examined separately. However, they did find that neighborhood socioeconomic disadvantage was associated with a higher ratio of 24-hour urinary sodium to potassium excretion, which has been associated with higher prevalence of hypertension. In a subsequent study by the same group of investigators, greater neighborhood availability of confectionery stores/bakeries selling highly processed and convenience food items was associated with lower 24-hour urinary potassium excretion and higher ratio of urinary sodium to potassium excretion. ${ }^{94}$ Further, higher neighborhood availability of stores selling fruits and vegetables was associated with a lower 24-hour urinary sodium to potassium excretion ratio. Finally, in a study of urinary sodium and potassium excretion in black and white individuals living in Birmingham, AL or Chicago, IL who participated in the Treatment of Mild Hypertension Study, urinary sodium to potassium ratios were noted to be significantly higher in individuals living in Birmingham as compared to those living in Chicago irrespective of race, highlighting geographic differences in dietary sodium and potassium consumption that may be partly related to regional differences in food store availability. ${ }^{95}$

No studies have specifically examined the association of contextual poverty with sodium intake in CKD patients. Despite this, given the tight link between processed and fast foods with added salt and sodium-based food additives as well as observational studies showing an association of neighborhood poverty with increased sodium and/or ratio of sodium to potassium intake, it is quite likely that reduced access to grocery stores that offer affordable low-sodium food options increases the consumption of sodium in CKD patients.

Phosphorus Intake-Many of the same factors underlying the association of contextual poverty with excess sodium intake hold for phosphorus consumption in individuals with 
CKD. This is largely due to the nearly ubiquitous presence of phosphorus-based food additives in the modern food supply. Phosphorus-based additive use in food manufacturing spiked in the latter half of the $20^{\text {th }}$ century, ${ }^{96}$ substantially augmenting the total phosphorus content of modern diets. These additives serve a number of critical functions for food manufacturing, including $\mathrm{pH}$ stabilization, metal cation sequestration, emulsification, leavening, hydration, and bactericidal actions. ${ }^{96}$ While phosphorus additives in meat products have generated the greatest attention, the magnitude of the use of phosphorus additives in the meat industry pales in comparison to that of the baking industry, which utilizes the highest quantities of phosphorus additives because of the key role that phosphorus acids play as dough leavening agents. ${ }^{97}$ This is important in that many cheap, energy-dense food products purchased by individuals with low socioeconomic status include baked products.

Unlike sodium, phosphorus is naturally abundant in the food supply. Therefore, most individuals in the U.S. easily receive-and in fact usually exceed - the recommended daily allowance (RDA) of dietary phosphorus. The high levels of phosphorus additives in processed foods augments phosphorus intake even further, ${ }^{98}$ with estimates ranging from 250 to $1,000 \mathrm{mg}$ of extra phosphorus per day in older studies. ${ }^{99-101}$ More contemporary studies have shown that the contribution of phosphorus additives to total phosphorus per day remains quite high in diets rich in highly-processed foods. León et al. selected the top five best-selling food products containing phosphorus additives within fifteen general food categories from a commercially-available dataset of grocery sales in northeast Ohio and matched them one-to-one to similar products without phosphorus additives. ${ }^{102}$ These investigators then purchased both additive-containing and non-additive-containing products from local food stores and measured the phosphorus content after preparation of the food items according to standard practices. They then developed sample meals using analyzed matched foods to approximate the mean calorie, protein, carbohydrate and total fat intake of US adults as estimated by national databases. They found that, as compared to additive-free foods, additive-rich foods were estimated to contribute $736 \pm 91 \mathrm{mg}$ extra phosphorus consumption per day. Similarly, Carrigan et al. examined the contribution of phosphorusbased food additives to the total phosphorus content of processed foods by developing separate four-day menus for a low-additive and additive-enhanced diet using Nutrition Data System for Research software. ${ }^{103}$ The low-additive diet was designed to conform to United States Department of Agriculture guidelines for energy and phosphorus intake ( 2,000 kcal per day and $900 \mathrm{mg}$ of phosphorus per day) and contained minimally-processed foods. The additive-enhanced diet contained the same food items as the low-additive diet except that highly-processed foods were substituted for minimally-processed foods. Food items from both diets were collected, blended, and sent for measurement of energy and nutrient intake. The main findings of this study were that, when averaged over the four menu days, measured phosphorus contents of the additive-enhanced diet were $606 \pm 125$ higher than the low-additive diet, respectively, representing a $60 \%$ increase in total phosphorus content on average. Interestingly, this study also showed that measured sodium content of the additiveenhanced diet was on average 1,329 $\pm 642 \mathrm{mg}$ higher per day than the low-additive diet, further underscoring the importance of added salt and sodium-based food additives to total sodium consumption in highly processed diets. 
A particular problem with phosphorus additives in processed and fast foods is that they are typically unaccounted in the estimated phosphorus content of processed foods because food manufacturers are not required to list their quantities. ${ }^{104}$ Thus, they represent a largely "hidden" dietary phosphorus load in typical American diets. Further, they are absorbed with much greater efficiency in the gut (>90\%) than organic forms of phosphorus in animal or vegetable proteins ( $\sim 50-60 \%$ ), with potentially important consequences. ${ }^{104}$ Indeed, a study showed that foods with higher phosphorus bioavailability significantly increased serum phosphorus and fibroblast growth factor 23 (FGF23) concentrations in CKD patients, 105 suggesting that the high bioavailability of phosphorus additives may potentiate their adverse impact on phosphorus homeostasis in CKD.

Given the strong association of neighborhood characteristics with consumption of processed and fast foods reviewed above, limited access to healthy food options likely plays an important role in promoting excess phosphorus intake by increasing the consumption of highly-processed foods. To date, however, few studies have specifically looked at whether access to food stores or fast food restaurants impacts phosphorus intake. Nevertheless, studies looking at the association of individual-level markers of socioeconomic status and biochemical markers of phosphorus homeostasis may provide important clues. Several studies have shown that lower annual family income was associated with higher serum phosphorus in participants of NHANES and with higher serum phosphorus and FGF23 concentrations in participants of the Chronic Renal Insufficiency Cohort Study. ${ }^{106-108}$ In contrast, a study using the MESA database showed no association of annual family income with serum phosphorus concentrations when controlling for other factors, particularly female sex. ${ }^{109}$ Further, this study showed that consumption of fast foods was not associated with serum phosphorus concentrations. In the aggregate, these data suggest that socioeconomic status partly impacts biochemical measures of phosphorus homeostasis, though the magnitude and strength of this association were inconsistent and not clearly related to access to food sources. Further studies using more sensitive measures of dietary phosphorus intake such as 24-hour urinary phosphorus excretion are needed to determine the association of neighborhood characteristics and food insecurity with phosphorus intake in CKD patients.

\section{Contextual poverty, nutrition and CKD: summary}

Nutrition plays a vital role in optimizing CKD outcomes. As emphasized by the data reviewed above, any serious attempt to modify diet intake in CKD patients must take into account where and what kinds of foods are being purchased for consumption at home. This must be done with appropriate sensitivity to the types of food establishments which are available in the neighborhood that each individual patient lives in, with appropriate tailoring of advice to the particular circumstances that the patient is faced with. Research into emerging technologies or other strategies that can be used to improve access to healthier food items, particularly resource-scarce communities, is needed to combat the impact of contextual poverty on CKD outcomes. Given the enduring link between poverty and CKD, developing sustainable strategies to improve access to healthier foods should be among the highest priorities in public health research. 


\section{Acknowledgments}

Dr. Gutiérrez was supported by grants R03DK095005 and R01NS080850.

\section{References}

1. Ikizler TA, Hakim RM. Nutrition in end-stage renal disease. Kidney Int. 1996; 50(2):343-357. [PubMed: 8840260]

2. Owen WF Jr, Lew NL, Liu Y, Lowrie EG, Lazarus JM. The urea reduction ratio and serum albumin concentration as predictors of mortality in patients undergoing hemodialysis. N Engl J Med. 1993; 329(14):1001-1006. [PubMed: 8366899]

3. Darmon N, Drewnowski A. Does social class predict diet quality? Am J Clin Nutr. 2008; 87(5): 1107-1117. [PubMed: 18469226]

4. James WP, Nelson M, Ralph A, Leather S. Socioeconomic determinants of health. The contribution of nutrition to inequalities in health. BMJ. 1997; 314(7093):1545-1549. [PubMed: 9183207]

5. Morland K, Wing S, Diez Roux A. The contextual effect of the local food environment on residents' diets: the atherosclerosis risk in communities study. Am J Public Health. 2002; 92(11):1761-1767. [PubMed: 12406805]

6. Diez Roux AV. Investigating neighborhood and area effects on health. Am J Public Health. 2001; 91(11):1783-1789. [PubMed: 11684601]

7. Shoham DA, Vupputuri S, Kshirsagar AV. Chronic kidney disease and life course socioeconomic status: a review. Adv Chronic Kidney Dis. 2005; 12(1):56-63. [PubMed: 15719334]

8. Filipowicz R, Beddhu S. Optimal nutrition for predialysis chronic kidney disease. Adv Chronic Kidney Dis. 2013; 20(2):175-180. [PubMed: 23439377]

9. Ikizler TA. Optimal nutrition in hemodialysis patients. Adv Chronic Kidney Dis. 2013; 20(2):181189. [PubMed: 23439378]

10. Stenvinkel P, Zoccali C, Ikizler TA. Obesity in CKD--what should nephrologists know? J Am Soc Nephrol. 2013; 24(11):1727-1736. [PubMed: 24115475]

11. Burton JO, Gray LJ, Webb DR, et al. Association of anthropometric obesity measures with chronic kidney disease risk in a non-diabetic patient population. Nephrol Dial Transplant. 2012; 27(5): 1860-1866. [PubMed: 21965589]

12. Foster MC, Hwang SJ, Larson MG, et al. Overweight, obesity, and the development of stage 3 CKD: the Framingham Heart Study. Am J Kidney Dis. 2008; 52(1):39-48. [PubMed: 18440684]

13. Hsu CY, McCulloch CE, Iribarren C, Darbinian J, Go AS. Body mass index and risk for end-stage renal disease. Ann Intern Med. 2006; 144(1):21-28. [PubMed: 16389251]

14. Hsu CY, Iribarren C, McCulloch CE, Darbinian J, Go AS. Risk factors for end-stage renal disease: 25-year follow-up. Arch Intern Med. 2009; 169(4):342-350. [PubMed: 19237717]

15. Iseki K, Ikemiya Y, Kinjo K, Inoue T, Iseki C, Takishita S. Body mass index and the risk of development of end-stage renal disease in a screened cohort. Kidney Int. 2004; 65(5):1870-1876. [PubMed: 15086929]

16. Kramer H, Luke A, Bidani A, Cao G, Cooper R, McGee D. Obesity and prevalent and incident CKD: the Hypertension Detection and Follow-Up Program. Am J Kidney Dis. 2005; 46(4):587594. [PubMed: 16183412]

17. Vivante A, Golan E, Tzur D, et al. Body mass index in 1.2 million adolescents and risk for endstage renal disease. Arch Intern Med. 2012; 172(21):1644-1650. [PubMed: 23108588]

18. Kanasaki K, Kitada M, Kanasaki M, Koya D. The biological consequence of obesity on the kidney. Nephrol Dial Transplant. 2013; 28(Suppl 4):iv1-7. [PubMed: 23743020]

19. Camici M, Galetta F, Abraham N, Carpi A. Obesity-related glomerulopathy and podocyte injury: a mini review. Front Biosci (Elite Ed). 2012; 4:1058-1070. [PubMed: 22201936]

20. Tran HA. Obesity-related glomerulopathy. J Clin Endocrinol Metab. 2004; 89(12):6358. [PubMed: 15579804] 
21. Chagnac A, Weinstein T, Korzets A, Ramadan E, Hirsch J, Gafter U. Glomerular hemodynamics in severe obesity. American Journal of Physiology-Renal Physiology. 2000; 278(5):F817-F822. [PubMed: 10807594]

22. Kopple JD, Feroze U. The effect of obesity on chronic kidney disease. Journal of renal nutrition : the official journal of the Council on Renal Nutrition of the National Kidney Foundation. 2011; 21(1):66-71.

23. Kalantar-Zadeh K, Abbott KC, Salahudeen AK, Kilpatrick RD, Horwich TB. Survival advantages of obesity in dialysis patients. Am J Clin Nutr. 2005; 81(3):543-554. [PubMed: 15755821]

24. Kovesdy CP, Anderson JE, Kalantar-Zadeh K. Paradoxical association between body mass index and mortality in men with CKD not yet on dialysis. Am J Kidney Dis. 2007; 49(5):581-591. [PubMed: 17472839]

25. Kalantar-Zadeh K, Kovesdy CP, Derose SF, Horwich TB, Fonarow GC. Racial and survival paradoxes in chronic kidney disease. Nat Clin Pract Nephrol. 2007; 3(9):493-506. [PubMed: 17717562]

26. Beddhu S. The body mass index paradox and an obesity, inflammation, and atherosclerosis syndrome in chronic kidney disease. Semin Dial. 2004; 17(3):229-232. [PubMed: 15144550]

27. Kramer H, Shoham D, McClure LA, et al. Association of waist circumference and body mass index with all-cause mortality in CKD: The REGARDS (Reasons for Geographic and Racial Differences in Stroke) Study. Am J Kidney Dis. 2011; 58(2):177-185. [PubMed: 21601327]

28. Beddhu S, Pappas LM, Ramkumar N, Samore M. Effects of body size and body composition on survival in hemodialysis patients. J Am Soc Nephrol. 2003; 14(9):2366-2372. [PubMed: 12937315]

29. National Kidney Foundation. K/DOQI Clinical Practice Guidelines for Nutrition in Chronic Renal Failure. Am J Kidney Dis. 2000; 35 (suppl 2):S1-140. [PubMed: 10895784]

30. Lin J, Judd S, Le A, et al. Associations of dietary fat with albuminuria and kidney dysfunction. Am J Clin Nutr. 2010; 92(4):897-904. [PubMed: 20702608]

31. Patel KP, Luo FJ, Plummer NS, Hostetter TH, Meyer TW. The production of p-cresol sulfate and indoxyl sulfate in vegetarians versus omnivores. Clin J Am Soc Nephrol. 2012; 7(6):982-988. [PubMed: 22490877]

32. Hall WL. Dietary saturated and unsaturated fats as determinants of blood pressure and vascular function. Nutr Res Rev. 2009; 22(1):18-38. [PubMed: 19243668]

33. Scialla JJ, Anderson CA. Dietary acid load: a novel nutritional target in chronic kidney disease? Adv Chronic Kidney Dis. 2013; 20(2):141-149. [PubMed: 23439373]

34. He FJ, MacGregor GA. A comprehensive review on salt and health and current experience of worldwide salt reduction programmes. J Hum Hypertens. 2009; 23(6):363-384. [PubMed: 19110538]

35. Meneton P, Jeunemaitre X, de Wardener HE, MacGregor GA. Links between dietary salt intake, renal salt handling, blood pressure, and cardiovascular diseases. Physiol Rev. 2005; 85(2):679715. [PubMed: 15788708]

36. Cook NR, Cutler JA, Obarzanek E, et al. Long term effects of dietary sodium reduction on cardiovascular disease outcomes: observational follow-up of the trials of hypertension prevention (TOHP). BMJ. 2007; 334(7599):885-888. [PubMed: 17449506]

37. He FJ, MacGregor GA. Effect of modest salt reduction on blood pressure: a meta-analysis of randomized trials. Implications for public health. J Hum Hypertens. 2002; 16(11):761-770. [PubMed: 12444537]

38. Forte JG, Miguel JM, Miguel MJ, de Padua F, Rose G. Salt and blood pressure: a community trial. J Hum Hypertens. 1989; 3(3):179-184. [PubMed: 2671369]

39. Sacks FM, Svetkey LP, Vollmer WM, et al. Effects on blood pressure of reduced dietary sodium and the Dietary Approaches to Stop Hypertension (DASH) diet. DASH-Sodium Collaborative Research Group. N Engl J Med. 2001; 344(1):3-10. [PubMed: 11136953]

40. McMahon EJ, Bauer JD, Hawley CM, et al. A randomized trial of dietary sodium restriction in CKD. J Am Soc Nephrol. 2013; 24(12):2096-2103. [PubMed: 24204003]

41. Sanders PW. Vascular consequences of dietary salt intake. Am J Physiol Renal Physiol. 2009; 297(2):F237-243. [PubMed: 19339634] 
42. Roos JC, Koomans HA, Dorhout Mees EJ, Delawi IM. Renal sodium handling in normal humans subjected to low, normal, and extremely high sodium supplies. Am J Physiol. 1985; 249(6 Pt 2):F941-947. [PubMed: 3907374]

43. Cianciaruso B, Bellizzi V, Minutolo R, et al. Renal adaptation to dietary sodium restriction in moderate renal failure resulting from chronic glomerular disease. J Am Soc Nephrol. 1996; 7(2): 306-313. [PubMed: 8785401]

44. Koomans HA, Roos JC, Dorhout Mees EJ, Delawi IM. Sodium balance in renal failure. A comparison of patients with normal subjects under extremes of sodium intake. Hypertension. 1985; 7(5):714-721. [PubMed: 3897045]

45. Krikken JA, Laverman GD, Navis G. Benefits of dietary sodium restriction in the management of chronic kidney disease. Curr Opin Nephrol Hypertens. 2009; 18(6):531-538. [PubMed: 19713840]

46. Ritz E. Salt--friend or foe? Nephrol Dial Transplant. 2006; 21(8):2052-2056. [PubMed: 16384834]

47. Ibels LS, Alfrey AC, Haut L, Huffer WE. Preservation of function in experimental renal disease by dietary restriction of phosphate. N Engl J Med. 1978; 298(3):122-126. [PubMed: 619240]

48. Haut LL, Alfrey AC, Guggenheim S, Buddington B, Schrier N. Renal toxicity of phosphate in rats. Kidney Int. 1980; 17(6):722-731. [PubMed: 7412107]

49. Karlinsky ML, Haut L, Buddington B, Schrier NA, Alfrey AC. Preservation of renal function in experimental glomerulonephritis. Kidney Int. 1980; 17(3):293-302. [PubMed: 7401449]

50. Koizumi T, Murakami K, Nakayama H, Kuwahara T, Yoshinari O. Role of dietary phosphorus in the progression of renal failure. Biochem Biophys Res Commun. 2002; 295(4):917-921. [PubMed: 12127982]

51. Lumlertgul D, Burke TJ, Gillum DM, et al. Phosphate depletion arrests progression of chronic renal failure independent of protein intake. Kidney Int. 1986; 29(3):658-666. [PubMed: 3702220]

52. Brown SA, Crowell WA, Barsanti JA, White JV, Finco DR. Beneficial effects of dietary mineral restriction in dogs with marked reduction of functional renal mass. J Am Soc Nephrol. 1991; 1(10):1169-1179. [PubMed: 1768812]

53. Finco DR, Brown SA, Crowell WA, Groves CA, Duncan JR, Barsanti JA. Effects of phosphorus/ calcium-restricted and phosphorus/calcium-replete $32 \%$ protein diets in dogs with chronic renal failure. Am J Vet Res. 1992; 53(1):157-163. [PubMed: 1539911]

54. Ross LA, Finco DR, Crowell WA. Effect of dietary phosphorus restriction on the kidneys of cats with reduced renal mass. Am J Vet Res. 1982; 43(6):1023-1026. [PubMed: 7103172]

55. Nagano N, Miyata S, Obana S, et al. Sevelamer hydrochloride, a phosphate binder, protects against deterioration of renal function in rats with progressive chronic renal insufficiency. Nephrol Dial Transplant. 2003; 18(10):2014-2023. [PubMed: 13679475]

56. Maschio G, Oldrizzi L, Tessitore N, et al. Effects of dietary protein and phosphorus restriction on the progression of early renal failure. Kidney Int. 1982; 22(4):371-376. [PubMed: 7176336]

57. Maschio G, Oldrizzi L, Tessitore N, et al. Early dietary protein and phosphorus restriction is effective in delaying progression of chronic renal failure. Kidney Int Suppl. 1983; 16:S273-277. [PubMed: 6588264]

58. Barsotti G, Morelli E, Giannoni A, Guiducci A, Lupetti S, Giovannetti S. Restricted phosphorus and nitrogen intake to slow the progression of chronic renal failure: a controlled trial. Kidney Int Suppl. 1983; 16:S278-284. [PubMed: 6376918]

59. Barsotti G, Giannoni A, Morelli E, et al. The decline of renal function slowed by very low phosphorus intake in chronic renal patients following a low nitrogen diet. Clin Nephrol. 1984; 21(1):54-59. [PubMed: 6705274]

60. Shoham DA, Vupputuri S, Kaufman JS, et al. Kidney disease and the cumulative burden of life course socioeconomic conditions: the Atherosclerosis Risk in Communities (ARIC) study. Soc Sci Med. 2008; 67(8):1311-1320. [PubMed: 18667261]

61. Diez-Roux AV, Nieto FJ, Caulfield L, Tyroler HA, Watson RL, Szklo M. Neighbourhood differences in diet: the Atherosclerosis Risk in Communities (ARIC) Study. J Epidemiol Community Health. 1999; 53(1):55-63. [PubMed: 10326055]

62. Morland K, Wing S, Diez Roux A, Poole C. Neighborhood characteristics associated with the location of food stores and food service places. Am J Prev Med. 2002; 22(1):23-29. [PubMed: 11777675] 
63. Moore LV, Diez Roux AV. Associations of neighborhood characteristics with the location and type of food stores. Am J Public Health. 2006; 96(2):325-331. [PubMed: 16380567]

64. Moore LV, Diez Roux AV, Nettleton JA, Jacobs DR, Franco M. Fast-food consumption, diet quality, and neighborhood exposure to fast food: the multi-ethnic study of atherosclerosis. Am J Epidemiol. 2009; 170(1):29-36. [PubMed: 19429879]

65. Duran AC, Diez Roux AV, do Latorre MR, Jaime PC. Neighborhood socioeconomic characteristics and differences in the availability of healthy food stores and restaurants in Sao Paulo, Brazil. Health Place. 2013; 23:39-47. [PubMed: 23747923]

66. Curl CL, Beresford SA, Hajat A, et al. Associations of organic produce consumption with socioeconomic status and the local food environment: Multi-Ethnic Study of Atherosclerosis (MESA). PLoS One. 2013; 8(7):e69778. [PubMed: 23936098]

67. Dubowitz T, Heron M, Bird CE, et al. Neighborhood socioeconomic status and fruit and vegetable intake among whites, blacks, and Mexican Americans in the United States. Am J Clin Nutr. 2008; 87(6):1883-1891. [PubMed: 18541581]

68. Core indicators of nutritional state for difficult-to-sample populations. J Nutr. 1990; 120 (Suppl 11):1559-1600. [PubMed: 2243305]

69. Drewnowski A. Obesity, diets, and social inequalities. Nutr Rev. 2009; 67 (Suppl 1):S36-39. [PubMed: 19453676]

70. Drewnowski A. The economics of food choice behavior: why poverty and obesity are linked. Nestle Nutr Inst Workshop Ser. 2012; 73:95-112. [PubMed: 23128769]

71. Leung CW, Gregorich SE, Laraia BA, Kushi LH, Yen IH. Measuring the neighborhood environment: associations with young girls' energy intake and expenditure in a cross-sectional study. Int J Behav Nutr Phys Act. 2010; 7:52. [PubMed: 20515487]

72. Saelens BE, Sallis JF, Frank LD, et al. Obesogenic neighborhood environments, child and parent obesity: the Neighborhood Impact on Kids study. Am J Prev Med. 2012; 42(5):e57-64. [PubMed: 22516504]

73. Keita AD, Casazza K, Thomas O, Fernandez JR. Neighborhood perceptions affect dietary behaviors and diet quality. J Nutr Educ Behav. 2011; 43(4):244-250. [PubMed: 20880752]

74. Hearst MO, Pasch KE, Laska MN. Urban v. suburban perceptions of the neighbourhood food environment as correlates of adolescent food purchasing. Public Health Nutr. 2012; 15(2):299_ 306. [PubMed: 21859510]

75. Cameron AJ, Thornton LE, McNaughton SA, Crawford D. Variation in supermarket exposure to energy-dense snack foods by socio-economic position. Public Health Nutr. 2013; 16(7):11781185. [PubMed: 22613746]

76. Rose D, Richards R. Food store access and household fruit and vegetable use among participants in the US Food Stamp Program. Public Health Nutr. 2004; 7(8):1081-1088. [PubMed: 15548347]

77. Zenk SN, Schulz AJ, Hollis-Neely T, et al. Fruit and vegetable intake in African Americans income and store characteristics. Am J Prev Med. 2005; 29(1):1-9. [PubMed: 15958245]

78. Wahowiak L. Food deserts. Across America, there's food everywhere--and yet there's nothing to eat. Why? Diabetes Forecast. 2013; 66(9):50-53.

79. Yen IH, Yelin EH, Katz P, Eisner MD, Blanc PD. Perceived neighborhood problems and quality of life, physical functioning, and depressive symptoms among adults with asthma. Am J Public Health. 2006; 96(5):873-879. [PubMed: 16571704]

80. Yen IH, Kaplan GA. Poverty area residence and changes in physical activity level: evidence from the Alameda County Study. Am J Public Health. 1998; 88(11):1709-1712. [PubMed: 9807543]

81. Parks SE, Housemann RA, Brownson RC. Differential correlates of physical activity in urban and rural adults of various socioeconomic backgrounds in the United States. J Epidemiol Community Health. 2003; 57(1):29-35. [PubMed: 12490645]

82. Sallis JF, Bauman A, Pratt M. Environmental and policy interventions to promote physical activity. Am J Prev Med. 1998; 15(4):379-397. [PubMed: 9838979]

83. Scialla JJ, Appel LJ, Wolf M, et al. Plant protein intake is associated with fibroblast growth factor 23 and serum bicarbonate levels in patients with chronic kidney disease: the Chronic Renal Insufficiency Cohort study. Journal of renal nutrition : the official journal of the Council on Renal Nutrition of the National Kidney Foundation. 2012; 22(4):379-388. e371. 
84. Scialla JJ, Appel LJ, Astor BC, et al. Estimated net endogenous acid production and serum bicarbonate in African Americans with chronic kidney disease. Clin J Am Soc Nephrol. 2011; 6(7):1526-1532. [PubMed: 21700817]

85. Scialla JJ, Appel LJ, Astor BC, et al. Net endogenous acid production is associated with a faster decline in GFR in African Americans. Kidney Int. 2012; 82(1):106-112. [PubMed: 22475819]

86. James WP, Ralph A, Sanchez-Castillo CP. The dominance of salt in manufactured food in the sodium intake of affluent societies. Lancet. 1987; 1(8530):426-429. [PubMed: 2880223]

87. Stamler J, Elliott P, Dennis B, et al. INTERMAP: background, aims, design, methods, and descriptive statistics (nondietary). J Hum Hypertens. 2003; 17(9):591-608. [PubMed: 13679950]

88. Anderson CA, Appel LJ, Okuda N, et al. Dietary sources of sodium in China, Japan, the United Kingdom, and the United States, women and men aged 40 to 59 years: the INTERMAP study. J Am Diet Assoc. 2010; 110(5):736-745. [PubMed: 20430135]

89. Larson NI, Story MT, Nelson MC. Neighborhood environments: disparities in access to healthy foods in the U.S. Am J Prev Med. 2009; 36(1):74-81. [PubMed: 18977112]

90. Franco M, Diez Roux AV, Glass TA, Caballero B, Brancati FL. Neighborhood characteristics and availability of healthy foods in Baltimore. Am J Prev Med. 2008; 35(6):561-567. [PubMed: 18842389]

91. Miyaki K, Song Y, Taneichi S, et al. Socioeconomic status is significantly associated with dietary salt intakes and blood pressure in Japanese workers (J-HOPE Study). Int J Environ Res Public Health. 2013; 10(3):980-993. [PubMed: 23478398]

92. Keita AD, Casazza K, Thomas O, Fernandez JR. Neighborhood-level disadvantage is associated with reduced dietary quality in children. J Am Diet Assoc. 2009; 109(9):1612-1616. [PubMed: 19699843]

93. Murakami K, Sasaki S, Takahashi Y, Uenishi K. Neighborhood socioeconomic disadvantage is associated with higher ratio of 24-hour urinary sodium to potassium in young Japanese women. $\mathrm{J}$ Am Diet Assoc. 2009; 109(9):1606-1611. [PubMed: 19699842]

94. Murakami K, Sasaki S, Takahashi Y, Uenishi K. Neighbourhood food store availability in relation to $24 \mathrm{~h}$ urinary sodium and potassium excretion in young Japanese women. Br J Nutr. 2010; 104(7):1043-1050. [PubMed: 20420755]

95. Ganguli MC, Grimm RH Jr, Svendsen KH, Flack JM, Grandits GA, Elmer PJ. Urinary sodium and potassium profile of blacks and whites in relation to education in two different geographic urban areas. TOMHS Research Group. Treatment of Mild Hypertension Study. Am J Hypertens. 1999; 12(1 Pt 1):69-72. [PubMed: 10075387]

96. Molins, RA. Phosphates in Food. Boca Raton: CRC Press, Inc; 1991.

97. Stahl, JL.; Ellinger, RH. The use of phosphate in the cereal and baking industry. In: Deman, JM.; Melnychyn, P., editors. Symposium: Phosphate in Food Processing. Westport, CT: The Avi Publishing Company, Inc; 1971. p. 194-212.

98. Uribarri J. Phosphorus homeostasis in normal health and in chronic kidney disease patients with special emphasis on dietary phosphorus intake. Semin Dial. 2007; 20(4):295-301. [PubMed: 17635818]

99. Bell RR, Draper HH, Tzeng DY, Shin HK, Schmidt GR. Physiological responses of human adults to foods containing phosphate additives. J Nutr. 1977; 107(1):42-50. [PubMed: 189000]

100. Calvo MS. Dietary considerations to prevent loss of bone and renal function. Nutrition. 2000; 16(7-8):564-566. [PubMed: 10906557]

101. Oenning LL, Vogel J, Calvo MS. Accuracy of methods estimating calcium and phosphorus intake in daily diets. J Am Diet Assoc. 1988; 88(9):1076-1080. [PubMed: 3418003]

102. Leon JB, Sullivan CM, Sehgal AR. The prevalence of phosphorus-containing food additives in top-selling foods in grocery stores. Journal of renal nutrition : the official journal of the Council on Renal Nutrition of the National Kidney Foundation. 2013; 23(4):265-270. e262.

103. Carrigan A, Klinger A, Choquette SS, et al. Contribution of food additives to sodium and phosphorus content of diets rich in processed foods. Journal of renal nutrition : the official journal of the Council on Renal Nutrition of the National Kidney Foundation. 2014; 24(1):13-19. $19 \mathrm{e} 11$. 
104. Uribarri J, Calvo MS. Hidden sources of phosphorus in the typical American diet: does it matter in nephrology? Semin Dial. 2003; 16(3):186-188. [PubMed: 12753675]

105. Moe SM, Zidehsarai MP, Chambers MA, et al. Vegetarian compared with meat dietary protein source and phosphorus homeostasis in chronic kidney disease. Clin J Am Soc Nephrol. 2011; 6(2):257-264. [PubMed: 21183586]

106. Isakova T, Wahl P, Vargas GS, et al. Fibroblast growth factor 23 is elevated before parathyroid hormone and phosphate in chronic kidney disease. Kidney Int. 2011; 79(12):1370-1378.

[PubMed: 21389978]

107. Gutierrez OM, Anderson C, Isakova T, et al. Low socioeconomic status associates with higher serum phosphate irrespective of race. J Am Soc Nephrol. 2010; 21(11):1953-1960. [PubMed: 20847142]

108. Gutierrez OM, Isakova T, Enfield G, Wolf M. Impact of poverty on serum phosphate concentrations in the Third National Health and Nutrition Examination Survey. Journal of renal nutrition : the official journal of the Council on Renal Nutrition of the National Kidney Foundation. 2011; 21(2):140-148.

109. Gutierrez OM, Katz R, Peralta CA, et al. Associations of socioeconomic status and processed food intake with serum phosphorus concentration in community-living adults: the Multi-Ethnic Study of Atherosclerosis (MESA). Journal of renal nutrition : the official journal of the Council on Renal Nutrition of the National Kidney Foundation. 2012; 22(5):480-489. 


\section{CLINICAL SUMMARY}

- Nutrition plays a vital role in chronic kidney disease outcomes.

- Few factors impact diet quality as strongly as socioeconomic status.

- Contextual measures of poverty such as neighborhood socioeconomic status, availability of supermarkets and grocery stores, fast food restaurant density and transportation strongly influence total energy intake and the consumption of macro- and micronutrients such as protein, saturated fat, sodium and phosphorus that are associated with chronic kidney disease outcomes.

- Any serious attempt to modify the diet of individuals with chronic kidney disease must take into account the contextual effects of neighborhood environment on diet and tailor diet recommendations accordingly. 


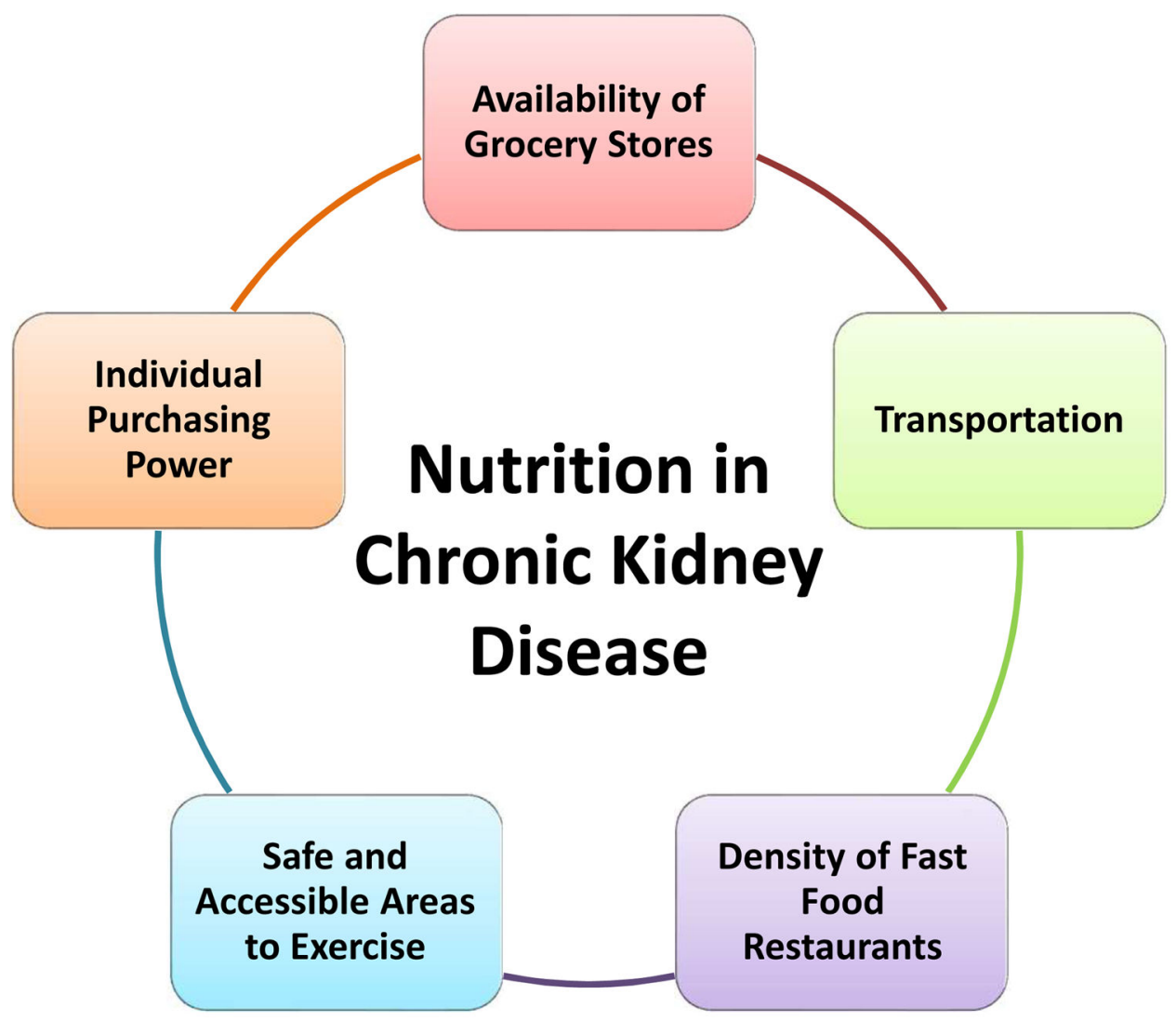

Figure.

Both individual and contextual socioeconomic factors affect the quality of nutrition in individuals with chronic kidney disease. As depicted in the figure, these factors are often interconnected, such that any one factor can accentuate the adverse impact of the others, compounding the overall adverse effects of poverty on the ability of individuals with chronic kidney disease to follow nutritional recommendations for a healthy diet. 